\title{
Amazon forest structure generates diurnal and seasonal variability in light utilization
}

\author{
Douglas C. Morton ${ }^{1}$, Jérémy Rubio ${ }^{1,2}$, Bruce D. Cook $^{1}$, Jean-Philippe Gastellu-Etchegorry ${ }^{2}$, Marcos Longo ${ }^{3}$, \\ Hyeungu Choi ${ }^{1,4}$, Maria Hunter ${ }^{5}$, and Michael Keller ${ }^{3,6}$ \\ ${ }^{1}$ NASA Goddard Space Flight Center, Greenbelt, MD 20771, USA \\ ${ }^{2}$ Centre d'Etudes Spatiales de la BIOsphère (CESBIO), UPS, CNES, CNRS, IRD, Université de Toulouse, \\ 31401 Toulouse CEDEX 9, France \\ ${ }^{3}$ Embrapa Monitoramento por Satélite, CEP: 13070-115, Campinas, SP, Brazil \\ ${ }^{4}$ Global Science \& Technology Inc., Greenbelt, MD 20770, USA \\ ${ }^{5}$ Earth Systems Research Center, University of New Hampshire, Durham, NH 03824, USA \\ ${ }^{6}$ USDA Forest Service, International Institute of Tropical Forestry, San Juan, PR 00926, USA \\ Correspondence to: Douglas C. Morton (douglas.morton@ nasa.gov)
}

Received: 11 November 2015 - Published in Biogeosciences Discuss.: 3 December 2015

Revised: 1 April 2016 - Accepted: 4 April 2016 - Published: 15 April 2016

\begin{abstract}
The complex three-dimensional (3-D) structure of tropical forests generates a diversity of light environments for canopy and understory trees. Understanding diurnal and seasonal changes in light availability is critical for interpreting measurements of net ecosystem exchange and improving ecosystem models. Here, we used the Discrete Anisotropic Radiative Transfer (DART) model to simulate leaf absorption of photosynthetically active radiation (lAPAR) for an Amazon forest. The 3-D model scene was developed from airborne lidar data, and local measurements of leaf reflectance, aerosols, and PAR were used to model lAPAR under direct and diffuse illumination conditions. Simulated $l$ APAR under clear-sky and cloudy conditions was corrected for light saturation effects to estimate light utilization, the fraction of $l$ APAR available for photosynthesis. Although the fraction of incoming PAR absorbed by leaves was consistent throughout the year (0.80-0.82), light utilization varied seasonally (0.67-0.74), with minimum values during the Amazon dry season. Shadowing and light saturation effects moderated potential gains in forest productivity from increasing PAR during dry-season months when the diffuse fraction from clouds and aerosols was low. Comparisons between DART and other models highlighted the role of 3-D forest structure to account for seasonal changes in light utilization. Our findings highlight how directional illumination and forest 3-D structure combine to influence diurnal and seasonal variabil-
\end{abstract}

ity in light utilization, independent of further changes in leaf area, leaf age, or environmental controls on canopy photosynthesis. Changing illumination geometry constitutes an alternative biophysical explanation for observed seasonality in Amazon forest productivity without changes in canopy phenology.

\section{Introduction}

Seasonal and interannual variability in vegetation productivity has profound impacts on the global carbon cycle (e.g., Poulter et al., 2014; Zeng et al., 2014; Keppel-Aleks et al., 2014; Le Quére et al., 2013; Gatti et al., 2014; Schimel et al., 2015; Cleveland et al., 2015). Understanding the mechanisms that link environmental variability and vegetation productivity is particularly important to constrain projections of Earth system feedbacks under future climate (e.g., KeppelAleks et al., 2014; Cox et al., 2013; Randerson, 2013; Boisier et al., 2015). Under current climate conditions, few tropical forest regions experience temperature limitations on biologic activity (Nemani et al., 2003), yet the degree to which water and light limit forest productivity remains controversial (e.g., Gatti et al., 2014; Morton et al., 2014; Phillips et al., 2009; Restrepo-Coupe et al., 2013; Samanta et al., 2012; Doughty et al., 2015; Guan et al., 2015). A detailed understanding of 
vegetation productivity over large spatial scales has proven elusive, even using remote sensing data and ecosystem models (e.g., Cleveland et al., 2015), given limited data on how species diversity (ter Steege et al., 2013), strategies for resource competition (e.g., Chave et al., 2010), and interactions between human and natural systems contribute to spatial and temporal dynamics of tropical forest productivity (e.g., Chen et al., 2010; Morton et al., 2013; Oliveira et al., 2007; Rap et al., 2015).

A more detailed investigation of the underlying mechanisms of Amazon forest productivity may offer new insights into the spatial and temporal variability in Amazon forest functioning. Previous studies have collected detailed data on forest growth or net carbon uptake to estimate seasonal (e.g., Saleska et al., 2003; Hutyra et al., 2007; Restrepo-Coupe et al., 2013; Malhi et al., 2015) or interannual variability in Amazon forest productivity (Nepstad et al., 2007; Gatti et al., 2010, 2014; Phillips et al., 2009; Doughty et al., 2015). A separate line of analysis has analyzed satellite data on vegetation structure and reflectance (e.g., Morton et al., 2014), solar-induced fluorescence (e.g., Joiner et al., 2011; Parazoo et al., 2013; Lee et al., 2013; Guan et al., 2015), canopy moisture (Frolking et al., 2011; Saatchi et al., 2013), rainfall (Lewis et al., 2011), terrestrial water storage (Chen et al., 2013b), and fire (Chen et al., 2013a) to characterize Amazon forest responses to large-scale environmental variability. Most previous studies directly compared environmental inputs and forest carbon dynamics without a mechanistic approach to translate environmental variability into differences in plant-available water or light (e.g., Huete et al., 2006; Lewis et al., 2011; Brando et al., 2010; Doughty et al., 2015; Guan et al., 2015). In addition, few studies have jointly considered seasonal dynamics in resource availability and forest responses beyond the scale of forest inventory plots or tower footprints (e.g., Oliveira et al., 2007; Nepstad et al., 2007; Doughty et al., 2015; da Costa et al., 2010; Asner et al., 2004; Stark et al., 2012), highlighting the important role of ecosystem models for regional carbon flux estimates.

Improving the representation of complex forest canopies in ecosystem models is essential to understand how variability in canopy illumination contributes to changes in Amazon forest productivity. Many ecosystem models are structured to partition light and water vertically, with only local consideration of horizontal resource competition (e.g., Moorcroft et al., 2001; Sitch et al., 2003; Krinner et al., 2005; Clark et al., 2011). The influence of vertical structure on light availability is widely recognized (e.g., Moorcroft et al., 2001; Clark et al., 2011; van der Tol et al., 2009; Gibelin et al., 2008; Sellers et al., 1992), yet the influence of horizontal variability in forest structure on light availability is rarely directly considered in dynamic global vegetation models (except see (Scheiter et al., 2013). Horizontal variability in forest 3-D structure results from fine-scale processes of canopy turnover and gap formation (e.g., Hunter et al., 2015; Asner et al., 2013); within-biome variability in tropical forest struc- ture may also reflect large-scale environmental, climatic, and disturbance gradients (e.g., Morton et al., 2014; Saatchi et al., 2011; Baccini et al., 2012; Malhi et al., 2006; EspíritoSanto et al., 2014). Models of intermediate complexity may not fully account for shadowing and light saturation effects that alter light utilization - the degree to which leaf-absorbed photosynthetically active radiation (lAPAR) can be used for photosynthesis.

Three-dimensional radiative transfer models offer the ability to quantify light interactions in complex forest canopies at the scale of individual leaves. A range of sensitivity studies highlight the importance of 3-D structure for the representation of visible and near-infrared scattering and absorption in forest canopies (Widlowski et al., 2011; Romanczyk et al., 2013; Gastellu-Etchegorry and Trichon, 1998). Several previous studies have used radiative transfer models to evaluate light absorption in tropical forest canopies and the impact of structure on forest productivity (e.g., Guillevic and GastelluEtchegorry, 1999; Alton et al., 2007a). There is broad interest in evidence for enhanced tropical forest productivity under diffuse light conditions (Oliveira et al., 2007; Rap et al., 2015; Mercado et al., 2009; Cirino et al., 2014; Alton et al., 2007b; Kanniah et al., 2012), but 3-D radiative transfer models have not been specifically used to evaluate the potential for seasonal changes in tropical forest productivity based on the interactions between illumination geometry (direct and diffuse) and tropical forest structure.

Here, we developed a detailed Amazon forest scene in the DART model (Gastellu-Etchegorry et al., 2015) using airborne lidar data and in situ measurements of forest structure and reflectance properties, PAR, and aerosols. The goal of this work was to evaluate the influence of Amazon forest structure on leaf absorption and light utilization by explicitly accounting for shadowing and light saturation under diurnal and seasonal variability in illumination conditions. By targeting the mechanisms that link PAR availability, absorption, and light utilization in a 3-D forest canopy, this study evaluated the potential responses of tropical forests to changing light conditions on seasonal or interannual timescales. This detailed investigation of light absorption, including the distribution of sunlit and shaded leaves, is also an important precursor for efforts to interpret global measurements of solarinduced fluorescence (SIF; e.g., Joiner et al., 2011; Guan et al., 2015).

\section{Methods}

\subsection{DART model simulations}

Diurnal and seasonal changes in the 3-D light environment of an Amazon forest were simulated using the DART model (Gastellu-Etchegorry et al., 2012, 2015). The 3-D forest scene $(50 \mathrm{~m} \times 50 \mathrm{~m})$ was developed using high-density airborne lidar data (> 20 returns per $\mathrm{m}^{2}$ ) from the Tapajós Na- 


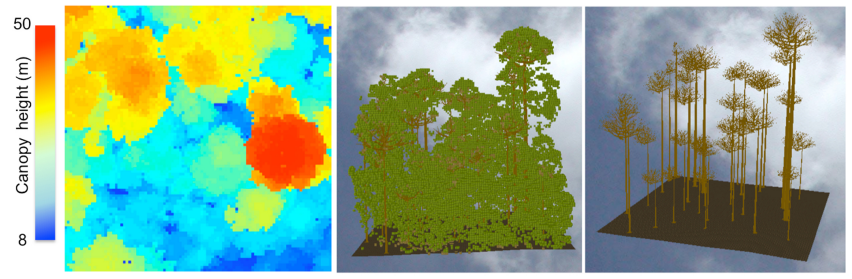

Figure 1. DART model scene of an Amazon forest $(50 \mathrm{~m} \times 50 \mathrm{~m})$ : (a) nadir view of canopy height, (b) oblique view of $1 \mathrm{~m}^{3}$ leaf voxels and woody architecture, and (c) tree objects for canopy tree crowns and stems.

tional Forest near Santarém, Pará, Brazil, and local measurements of leaf reflectance, litter reflectance, and leaf area (see extended data Fig. 1 in Morton et al., 2014). Discrete return airborne scanning lidar data were thinned to a consistent point density following methods described in (Leitold et al., 2015), and leaf area $\left(6 \mathrm{~m}^{2} \mathrm{~m}^{-2}\right.$, Asner et al., 2004) was allocated to $1 \mathrm{~m}^{3}$ voxels based on the distribution of multi-stop lidar returns, with leaf area index (LAI) distributed equally among lidar returns (Fig. 1). The lidar digital terrain model was used to represent surface topography in the 3-D scene.

Tree objects representing stems and branches were added for canopy trees to estimate PAR absorption by nonphotosynthetic canopy elements. Lidar-based estimates of tree height and crown dimensions were used to scale a generic tree object to represent the stem and branches for each canopy tree (Fig. 1). Woody structures were represented in DART using facets (triangles), so that light interception by branches and stems could be tracked separately from absorption by leaves or the ground surface. The geometry of facets is independent of voxel dimensions, allowing stems and woody branches to be represented at finer scales than leaf voxels. Previous studies have documented the importance of large branches for scattering and absorption of near-infrared energy in the forest canopy (Romanczyk et al., 2013). The use of tree objects in this study builds on the sensitivity study by Romanczyk et al. (2013) to investigate the impact of PAR absorption by woody branches within the canopy. Branches are rarely studied in tropical forests (except see Higuchi et al., 1998), and many radiative transfer and ecosystem models exclude light interactions with branches altogether.

DART simulations for cloudy and clear-sky conditions were run for $5 \mathrm{~h}$ per day and 1 day per month to produce 3-D estimates of daily, monthly, and annual leaf-absorbed photosynthetically active radiation ( $l$ APAR). DART simulations were configured to simulate a repeating (infinite) scene. Illumination geometry, aerosol optical depth, and incident PAR varied for each hourly simulation, but forest structure and reflectance properties were held constant. Hourly estimates of incident PAR and cloud cover were based on PAR measurements from the KM67 eddy flux tower within the Tapajós National Forest (08:00-09:00, 10:00-11:00, 12:001:00, 14:00-15:00, and 16:00-17:00 local time (Hutyra et al.,
2008); Table $\mathrm{S} 1$ in the Supplement). Cloud cover is highest during the wet season (December-June), with higher average incident PAR during dry-season months (July-November). At $3^{\circ} \mathrm{S}$ latitude, midday illumination conditions are near nadir in both March and September. Mean PAR values for cloudy and clear-sky conditions were estimated based on the distribution of hourly observations, with clear-sky conditions defined as hourly PAR values between 70 and $100 \%$ of maximum PAR for each hour and month (Table S1). Mean incident PAR for cloudy conditions was derived from observations $<70 \%$ of maximum PAR. These thresholds are similar to the approaches used in previous studies to interpret in situ measurements of incident radiation when no diffuse PAR sensor was available (Oliveira et al., 2007). A monthly climatology of aerosol optical depth was developed using data from the Belterra AERONET station (Holben et al., 1998) to simulate diffuse light from aerosol scattering under clear-sky DART simulations based on an updated atmospheric radiative transfer scheme in DART (Grau and Gastellu-Etchegorry, 2013). Cloudy conditions were simulated as $100 \%$ diffuse light. The treatment of illumination conditions as 0 or $100 \%$ cloudy is a convenient simplification that avoids the need to resolve cloud properties (e.g., optical thickness, size, altitude) and atmospheric transport attributes that could be the basis for a further study where more detailed ground measurements are available or using an Earth system model that simultaneously considers the impact of dynamic atmospheric processes on surface energy budgets. Combined hourly simulations were constructed using a weighted average of clear and cloudy DART model simulations for each hour and month.

Model simulations tracked light interactions with leaves, woody elements, and the ground surface (Table S2). Estimates of $l$ APAR $\left(\mu \mathrm{mol} \mathrm{m} \mathrm{m}^{-2} \mathrm{~s}^{-1}\right)$ for each $1 \mathrm{~m}^{3}$ voxel were post-processed to account for light saturation effects based on a photosynthetic light response curve from leaf-level measurements of tropical forest trees (Anacardium; Kitajima et al., 1997). Light utilization is therefore a unitless measure of "effective lAPAR," based on the fraction of light absorbed by leaves that can be used for photosynthesis in the absence of constraints based on leaf temperature or moisture stress (e.g., Doughty and Goulden, 2008). Fractional light utilization per unit leaf area decreased for light absorption $>225 \mu \mathrm{mol} \mathrm{m}^{-2} \mathrm{~s}^{-1}$, declining to approximately $0.8,0.6$, and 0.4 for $l$ APAR values of 360,450 , and $825 \mu \mathrm{mol} \mathrm{m}^{-2} \mathrm{~s}^{-1}$, respectively (Fig. 2). Throughout the manuscript, light saturation effects were calculated at the voxel scale and summed for the model scene based on the difference between absorbed and utilized light. Average light absorption by leaf material (turbid) in each voxel provided a conservative estimate of light saturation, since absorbed light was distributed across all leaf area in the voxel. Light saturation effects lead to lower light utilization based on the reduction in fractional light utilization above $225 \mu \mathrm{mol} \mathrm{m} \mathrm{m}^{-2} \mathrm{~s}^{-1}$, consistent with a shift from light to RuBisCO limitation of photosynthesis. 


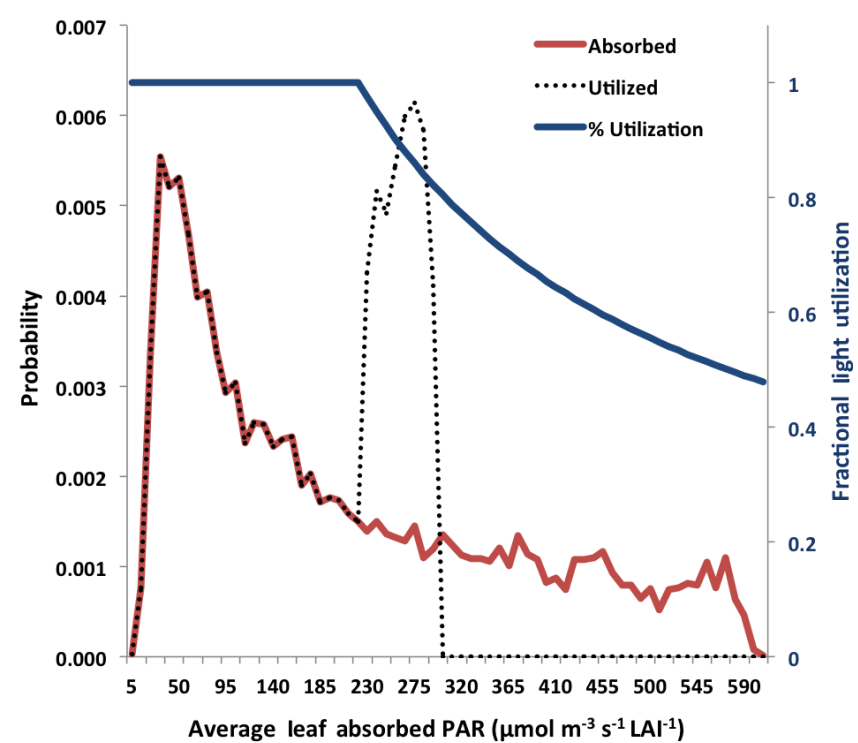

Figure 2. Probability distribution of average leaf-absorbed PAR (lAPAR, red) and absolute light utilization (dashed black) for the September 13:00 DART simulation. Fractional light utilization (blue) for different $l$ APAR values is plotted on the right $y$ axis, based on leaf measurements of light saturation from Kitajima et al. (1997). Absolute light utilization (dashed black) is the product of $l$ APAR (red) and fractional light utilization (blue). Light saturation reduces the effective leaf absorption for voxels with average $l$ APAR $>225 \mu \mathrm{mol} \mathrm{m}^{-3} \mathrm{~s}^{-1} \mathrm{LAI}^{-1}$.

\subsection{Model comparisons}

DART model simulations of $l$ APAR and light utilization were compared with two additional modeling approaches. Stark et al. (2012) used a light extinction model to estimate the vertical profile of light interception in Amazon forests. We used the vertical distribution of LAI across the DART scene and identical inputs for incident radiation (Table S1) to estimate the profile of light absorption following the methods described in Stark et al. (2012). We also used the Ecosystem Demography (ED) model (version 2.2; Longo, 2014) to simulate the vertical profile of light absorption and light utilization. The vertical profile of LAI was used to initialize an ED patch. Tower measurements of PAR (Hutyra et al., 2008) and the site coordinates were used to simulate incident radiation. ED model simulations also evaluated light absorption and utilization without moisture stress. Separate simulations considered the influence of dividing the DART scene into 1, 25, and 2500 patches in ED to evaluate the role of horizontal heterogeneity in forest structure on light absorption. Representing the DART scene as a single ED patch simulates the influence of the average forest structure. ED simulations with 25 patches $\left(100 \mathrm{~m}^{2}\right)$ are typical representations of forest structure in the model (Moorcroft et al., 2001), while simulations with 2500 patches $\left(1 \mathrm{~m}^{2}\right)$ examined the potential to

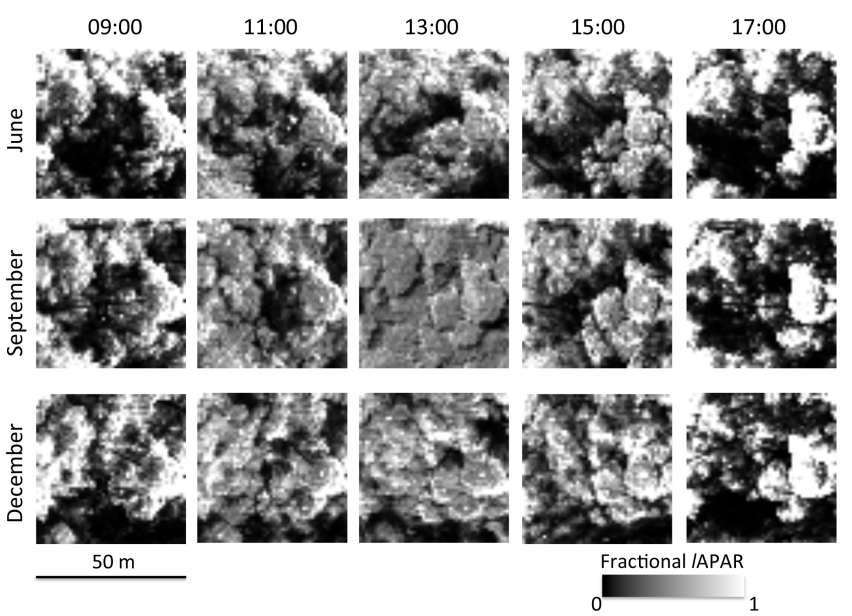

Figure 3. Illumination geometry alters the distribution of light absorption by leaves on a diurnal and seasonal basis. Simulation results for June, September, and December illustrate the distribution of fractional $l$ APAR across the model scene under direct illumination conditions, where diffuse light is modeled using observations of aerosol optical depth from AERONET. Fractional $l$ APAR exceeds 1 for some voxel columns with high interception of incoming PAR, especially with low sun angles in the morning (09:00 LT) and late afternoon (17:00 LT).

represent horizontal heterogeneity in vertical structure using the ED modeling approach.

\section{Results}

Light availability in tropical forests is dynamic on diurnal and seasonal timescales. Hourly distributions of $l$ APAR at the voxel scale highlighted diurnal variability in leaf absorption, including the fraction of leaves experiencing lightsaturated conditions (Fig. 3, Table S2). Shadowing effects were pronounced in early morning (09:00) and late afternoon (17:00) DART simulations, with most leaf voxels experiencing low $l$ APAR. The degree of shadowing changed seasonally, such that early morning overpass satellites (e.g., Terra MODIS, GOME-2) observe large seasonal changes in shadowing and illumination of tropical forests, altering the overall distribution of light absorption at the leaf level and the reflectance from sunlit and shaded leaves.

Seasonal variability in total $l$ APAR at the canopy scale was driven by a combination of changes in solar zenith angle and the fraction of diffuse light from clouds and aerosols (Fig. 4). Combined cloudy and clear-sky simulations showed highest total $l$ APAR in March and September, consistent with more even distribution of light under near-nadir midday illumination conditions in these months. March simulations were characterized by a more even distribution of $l$ APAR but lower incident radiation under cloudy conditions. Lower light utilization in September, based on light saturation effects under clear-sky simulations, led to similar estimates of 


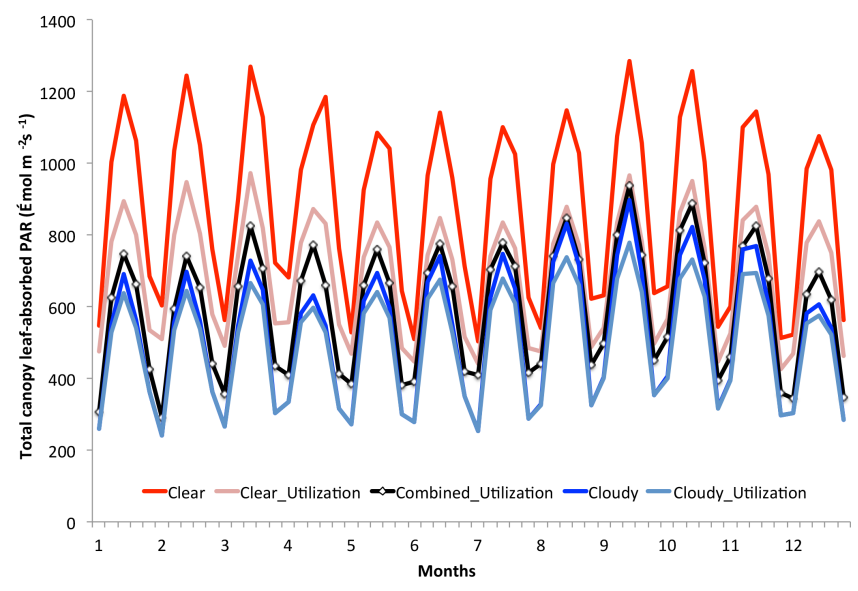

Figure 4. Cloudy (blue) and clear-sky DART simulations (red) were corrected for light saturations effects. Combined results (black line) are a weighted average of light utilization estimates from clear and cloudy simulations for $5 \mathrm{~h}$ per day and 1 day per month.

total utilized $l$ APAR in both months (Fig. 4). These cases illustrate how different mechanisms interact with forest structure to alter light availability for photosynthesis.

Shadowing, light saturation, and light absorption by woody branches reduced the fraction of absorbed PAR available for photosynthesis. At the scene scale, DART estimates of monthly fractional $l$ APAR varied between 0.8 and 0.85 , depending on illumination conditions (Fig. 5b). Fractional losses of $0.15-0.20$ of incoming PAR resulted from the combined influence of leaf reflectance $(0.036 \pm 0.014)$, wood absorption $(0.094 \pm 0.024)$, and light reaching the ground surface $(0.065 \pm 0.029$; Table S2). Light saturation effects at the leaf level, calculated as the difference between leaf absorption and light utilization, further reduced effective $l$ APAR. Mean saturation effects were lowest for simulations at 09:00 $(0.0428 \pm 0.0237)$ and highest in midday simulations (13:00, $0.121 \pm 0.027$ ), with a maximum of 0.17 in September (Table S2, see Fig. 2). At the monthly timescale, saturation effects varied from 0.05 to 0.13 , such that only $67-74 \%$ of incoming PAR was estimated to be available for photosynthesis.

Light saturation effects moderated the apparent benefit of increasing PAR during dry-season months (Figs. 4, 5). During July-November, saturation effects under midday conditions were similar in magnitude to combined APAR losses from absorption by woody elements and the ground (Table S2). Together, midday light saturation effects and nonleaf absorption led to the lowest light utilization during JulyNovember (Fig. 5). Canopy 3-D structure generated a decrease in light utilization during the dry season based on two competing processes. Lower cloud cover in the early dry season increased PAR at the top of canopy (Table S1, Fig. 5b), but lower sun angles and more direct radiation altered the distribution of light at the leaf level. Thus, monthly increases in
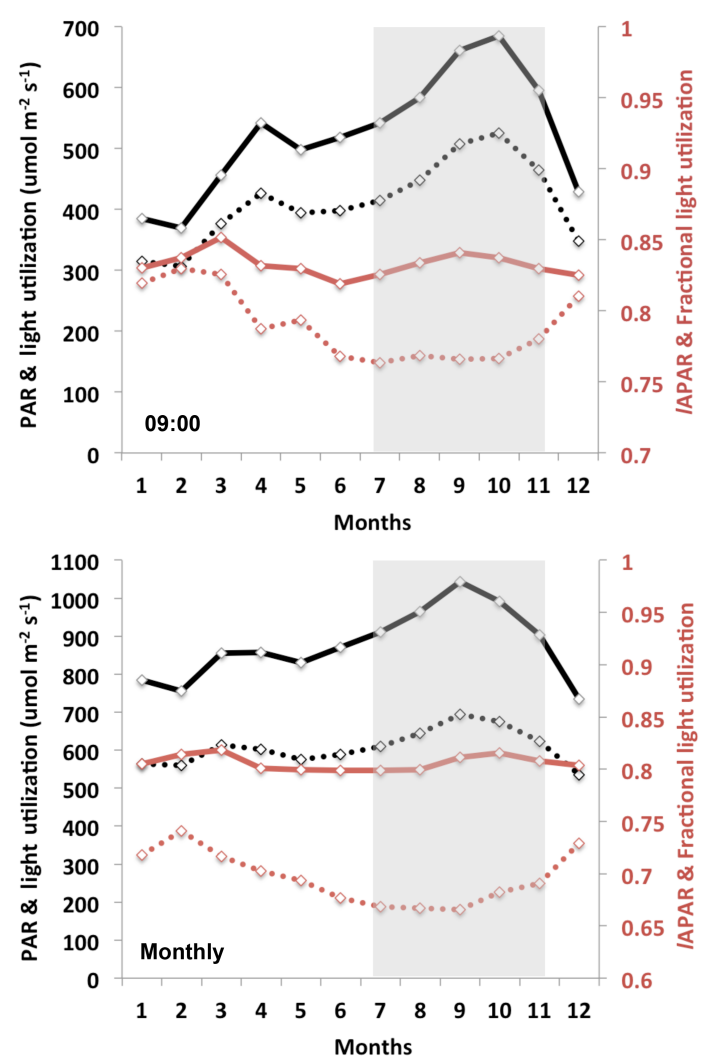

Figure 5. PAR (solid black) and modeled light utilization (dashed black) for DART simulations at 09:00 (a, top) and monthly average values (b, bottom), based on a weighted average of hourly DART simulations. Simulated monthly values of $l$ APAR (solid red) and fractional light utilization (dashed red) are plotted on the right-hand axis. Gray shading indicates dry-season months (JulyNovember).

PAR were not distributed across all leaves, as some canopy leaves were light saturated while shading other parts of the same crown or shorter neighboring trees.

This decrease in canopy light utilization can be described in terms of efficiency. Increased incident PAR between June and July $\left(+40.3 \mu \mathrm{mol} \mathrm{m}^{-2} \mathrm{~s}^{-1}\right)$ only resulted in a $50 \%$ relative increase in light utilization $\left(+20.0 \mu \mathrm{mol} \mathrm{m}^{-2} \mathrm{~s}^{-1}\right.$, Fig. 4, Table S2), with the remaining $l$ APAR lost to light saturation. Even under near-nadir illumination conditions in September, light saturation effects moderated the change in effective $l$ APAR to $65 \%$ of the relative increase in PAR between August and September. These cases highlight the need to consider how forest 3-D structure alters the distribution of $l$ APAR at the leaf level in order to estimate light utilization in tropical forests.

Horizontal variability in forest 3-D structure generated clear spatial and temporal differences in light absorption profiles and the vertical distribution of light saturation effects (Fig. 6). DART model results differed substantially from the depiction of diurnal variability in light interception from the 
exponential model (non-spatial) or the pseudo-spatial representation of forest structure in ED. The exponential model of light extinction overestimated total absorption by leaves compared to DART or ED under midday and afternoon illumination conditions (Fig. 6b, d). Adding more patches in ED model simulations generated light absorption profiles that were more similar to DART results, with horizontal differences in forest structure lowering cumulative light absorption from simulations with a single patch to a hyperparameterization of forest structure with 2500 patches. However, estimates of light utilization in ED exhibited different vertical profiles and cumulative lAPAR than in DART (Fig. 5b, d). ED model estimates of light utilization were more strongly influenced by total incident PAR than the diversity of patch environments, since each patch receives the same incident PAR at the top of canopy. Differences between models also reflect a more complete characterization of light interactions in DART, including 3-D representation of shading from neighboring trees and absorption by woody elements.

Light-saturated leaves were distributed throughout the vertical canopy profile under midday or diffuse illumination conditions in the DART simulations (Fig. 6a, Movie S1 in the Supplement). Greater light penetration in DART, with light saturation effects below mean canopy height, further distorted the vertical profile of DART light utilization relative to more simplified representations of forest structure (Fig. 6b). Evidence for greater light absorption by shorter canopy trees than taller canopy trees underscores the need for a full 3-D representation of the tropical forest light environment to accurately estimate tropical forest responses to changing light conditions. Horizontal variability in 3-D structure also generated a diversity of light environments at the forest floor (Movie S2). The frequency, intensity, and duration of sun flecks offers a promising avenue for studies of forest regeneration and the role of gap dynamics for the heterogeneity of light environments in the forest understory.

\section{Discussion}

Incident PAR at the top of a tropical forest canopy is an imperfect measure of light availability for photosynthesis. The 3-D structure of tropical forests, combined with diurnal and seasonal variability in direct and diffuse illumination, alters $l$ APAR and light saturation effects. Together, shadowing and saturation may reduce the amount of light available for photosynthesis by $11-23 \%$, given estimates of mean monthly light utilization in this study (0.67-0.74) and biome-wide estimates of Amazon FAPAR from satellite data (0.85-0.9; Senna et al., 2005). An accurate representation of light saturation effects in ecosystem models is critical to constrain potential gains in gross primary productivity from changing light levels under scenarios of future climate, including the influence of clouds and biomass burning aerosols on dif-
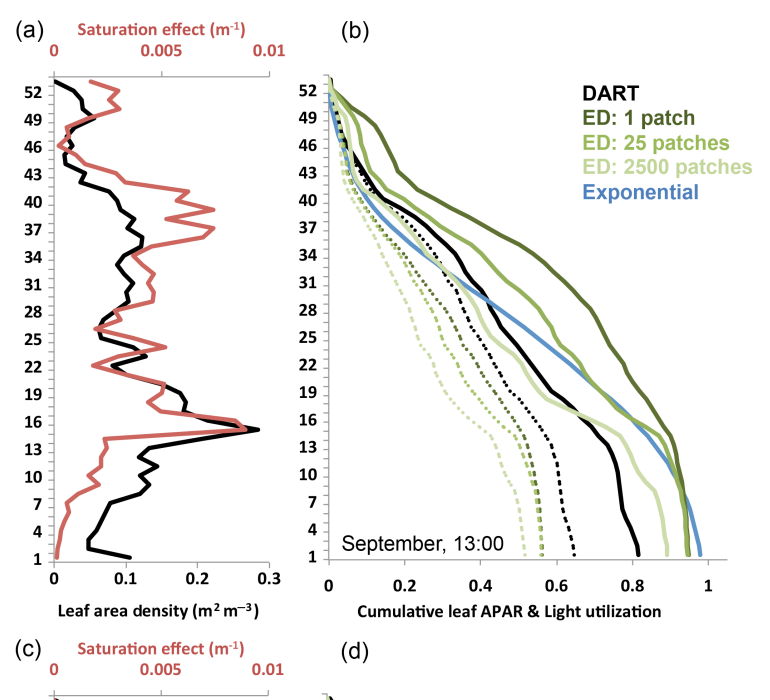

(d)
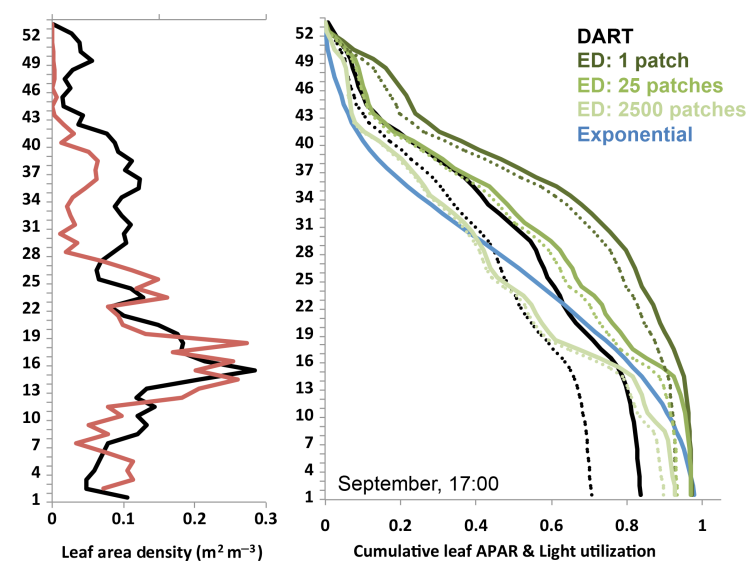

Figure 6. Forest 3-D structure alters total leaf absorption, light utilization, and the vertical distribution of light saturation effects compared to more simplified representations of the Amazon forest scene. (a) Vertical profiles of leaf area density (black) and light saturation effect (red, difference between absorbed and utilized light) for September 13:00 DART simulations. (b) DART cumulative $l$ APAR (black) and light utilization (dashed black); differences between light absorption and light utilization in DART simulations are plotted as the red curve in panel (a) to illustrate the vertical distribution of light saturation effects through the profile of canopy leaf area. DART results were compared to an exponential model of light extinction (blue, following Stark et al., 2012) and ED2 model simulations (green). Solid and dashed green lines depict cumulative leaf absorption and cumulative light utilization, respectively, for ED2 simulations with 1, 25, and 2500 patches. (c, d) Same as (a) and (b) for September 17:00 illumination conditions.

fuse light conditions (Rap et al., 2015; Mercado et al., 2009; Oliveira et al., 2007; Cirino et al., 2014; Kanniah et al., 2012). Ecosystem models of intermediate complexity may not fully account for shadowing and light saturation effects in tropical forests, including illumination differences among canopy trees and light penetration to lower canopy layers. For these models, it may be possible to leverage information on 
forest structure from satellite data to account for these processes. Forest types with greater vertical and horizontal heterogeneity generate stronger bidirectional reflectance effects in passive optical remote sensing data (Morton et al., 2014; Nagol et al., 2015), providing a proxy for fine-scale spatial variability in canopy structure.

Changing illumination geometry influences the distribution of light within the forest canopy, and this physical mechanism may partially explain patterns of seasonal carbon uptake in Amazon forests. Evidence for seasonal variability in light utilization in this study constitutes an alternate biophysical explanation for Amazon forest seasonality without concurrent changes in canopy phenology. Previous studies have estimated changes in photosynthetic capacity (PC) of Amazon forests based on the ratio of net ecosystem exchange to incident PAR (e.g., Hutyra et al., 2007; Restrepo-Coupe et al., 2013). One suggested mechanism for seasonal variability in PC is forest phenology. New leaves photosynthesize more efficiently than old leaves, and evidence for seasonal flushing of new leaves has therefore been hypothesized to promote greater PC from leaf demographics (Huete et al., 2006; Brando et al., 2010; Restrepo-Coupe et al., 2013; Wu et al., 2016). However, PC does not account for the influence of forest 3-D structure on light utilization from shadowing or light saturation effects. The impact of changes in leaf age or leaf characteristics (e.g., Kitajima et al., 1997) must therefore be evaluated based on the distribution of $l$ APAR at the leaf level. At present, is unclear whether seasonal changes in illumination are simply aliased to other seasonal phenomena in studies of PC, including phenology (Restrepo-Coupe et al., 2013; Medvigy et al., 2013; Wu et al., 2016), since these studies do not specifically separate leaf demography from other mechanisms for upregulation of PC. The results of this study highlight how directional illumination and forest 3-D structure combine to influence diurnal and seasonal variability in light utilization, independent of further changes in leaf area, leaf age, or environmental controls on canopy photosynthesis. DART model results emphasize the importance of light utilization (rather than PAR, FAPAR, or even lAPAR) to attribute changes in light availability to seasonal dynamics of Amazon forest productivity.

Whether the differences between DART and other models represent an offset or a bias depends on whether forest structure influences PAR absorption and utilization in consistent ways across seasons, latitudes, and forest types. In this study, lAPAR varied diurnally, but midday simulations (11:00 and 13:00) were more consistent across months, suggesting that shadowing may be less important than light saturation effects for estimates of midday photosynthesis in tropical forests. Saturation losses of $13-17 \%$ in midday simulations with DART underscore the need for leaf-level information to convert leaf absorption to light utilization. ED model simulations overestimated midday light saturation losses compared to DART and underestimated light saturation effects at lower sun angles, likely because all patches receive the same inci- dent PAR at the top of canopy (no shadowing from neighboring patches). Tropical forests present particular challenges for ecosystem models; regional differences in Amazon forest structure (Morton et al., 2014) interact with seasonal and interannual differences in diffuse illumination cloud cover and biomass burning aerosols. These challenges point to the potential benefits of developing more robust 3-D ecosystem models to estimate forest productivity under direct and diffuse illumination conditions.

Illumination conditions differ dramatically between the tropics and higher latitudes; temperate and boreal forests may never experience near-nadir illumination conditions approximated using 1-D light extinction profiles (Guillevic and Gastellu-Etchegorry, 1999), except under full diffuse illumination conditions. Seasonal variability in shadowing and light interception by woody elements may therefore be more important for understanding photosynthesis in these systems. Importantly, radiative transfer models such as DART must be coupled with ecosystem models to estimate how temperature and moisture stress reduce the utilization of $l$ APAR for midday, clear-sky simulations.

Light interactions at the leaf level are the basis for remote sensing approaches to monitor vegetation productivity. This study highlighted how horizontal variability in forest 3-D structure altered $l$ APAR and light absorption by woody elements and the ground surface. The influence of diurnal and seasonal variability in illumination is one factor that contributes to variability in surface reflectance estimates over Amazon forests (Morton et al., 2014; Nagol et al., 2015). Changes in the fraction of sunlit and shaded leaves, along with differences in the degree of light saturation, likely contributes to seasonal variability in SIF measurements from satellite platforms (e.g., Joiner et al., 2011; Guan et al., 2015), especially given the early morning overpass time of satellites such as GOME-2 (09:30, see Fig. 5a). To date, models and remote sensing approaches do not account for the role of local heterogeneity in forest structure as a mechanism for SIF variability (Joiner et al., 2011; Guan et al., 2015; Zhang et al., 2014).

The growing availability of lidar-based measurements of forest structure opens several important avenues for ecosystem model development. One underrepresented element of forest structure in ecosystem models is branches. In tropical forests, branches may account for one-third of the total aboveground biomass (Higuchi et al., 1998), yet few ecosystem models realistically account for the roles of branches and stem material for light interception or canopy turnover from branch falls. New measurement capabilities from terrestrial lidar scanning (TLS) systems, including multispectral instruments, offer new insights into the contribution of branches to 3-D structure and canopy reflectance in visible and nearinfrared wavelengths. TLS data also provide a detailed depiction of the vertical distribution of leaf area and the forest understory environment that could improve model parameterization. Finally, model simulation studies offer the potential 
to run simple or complex scenarios; in a future study, the single light saturation curve, leaf angle distribution, and leaf reflectance properties in this analysis could be modified based on new regional measurements to evaluate the influence of plant trait diversity on light responses in tropical forests.

In addition to data on branch structure, new field data are needed to constrain the influence of plant trait variability on canopy reflectance and light utilization. Recent studies highlight the potential for leaf demography to alter leaf reflectance on a seasonal basis (Chavana-Bryant et al., 2016; Wu et al., 2016; Brando et al., 2010). Without a broader sample of Amazon tree species, and additional data on transmittance and absorptance, it is unclear whether subtle and shortterm changes in leaf reflectance properties (Chavana-Bryant et al., 2016) are sufficient to alter PAR availability for canopy and understory trees. New data are also needed to model differences in light saturation among species, canopy positions, and leaf ages. Subsequent studies that combine forest 3-D structure (including branches) with leaf-level variability in light saturation could extend the work in this paper on the contributions from shadowing and light saturation to seasonal variability in light utilization in tropical forests.

This study illustrates the importance of realistic, 3-D representations of the forest canopy for accurate simulations of light availability in tropical forests. DART model results have important implications for both modeling and remote sensing of tropical forest ecosystems, including how the vertical and horizontal distributions of light saturation effects influence remote sensing measurements and model estimates of forest productivity. Radiative transfer models provide an important link between top-down estimates from remote sensing platforms and bottom-up estimates of forest structure and carbon fluxes from field and tower-based instruments. The growing availability of airborne lidar data offers the potential to investigate complex ecosystem interactions using DART or similar models to improve the representation of light utilization in ecosystem models.

\section{The Supplement related to this article is available online at doi:10.5194/bg-13-2195-2016-supplement.}

Acknowledgements. This research was funded by NASA's Terrestrial Ecology and Carbon Monitoring System programs and Brazil's National Council on Scientific Development \& Technology (CNPq) Science Without Borders Fellowship Program. Funding for lidar data collection was provided by the US Department of State, USAID, and the US SilvaCarbon Program. Lidar data are available from the Sustainable Landscapes Project: http://mapas.cnpm.embrapa.br/paisagenssustentaveis/.

Edited by: S. Zaehle

\section{References}

Alton, P. B., Ellis, R., Los, S. O., and North, P. R.: Improved global simulations of gross primary product based on a separate and explicit treatment of diffuse and direct sunlight, J. Geophys. Res.Atmos., 112, D07203, doi:10.1029/2006JD008022, 2007a.

Alton, P. B., North, P. R., and Los, S. O.: The impact of diffuse sunlight on canopy light-use efficiency, gross photosynthetic product and net ecosystem exchange in three forest biomes, Glob. Change Biol., 13, 776-787, doi:10.1111/j.13652486.2007.01316.x, 2007b.

Asner, G. P., Nepstad, D., Cardinot, G., and Ray, D.: Drought stress and carbon uptake in an amazon forest measured with spaceborne imaging spectroscopy, P. Natl. Acad. Sci. USA, 101, 6039-6044, 2004.

Asner, G. P., Kellner, J. R., Kennedy-Bowdoin, T., Knapp, D. E., Anderson, C., and Martin, R. E.: Forest canopy gap distributions in the southern peruvian amazon, PLoS ONE, 8, e60875, doi:10.1371/journal.pone.0060875, 2013.

Baccini, A., Goetz, S. J., Walker, W. S., Laporte, N. T., Sun, M., Sulla-Menashe, D., Hackler, J., Beck, P. S. A., Dubayah, R., Friedl, M. A., Samanta, S., and Houghton, R. A.: Estimated carbon dioxide emissions from tropical deforestation improved by carbon-density maps, Nature Climate Change, 2, 182-185, 2012.

Boisier, J. P., Ciais, P., Ducharne, A., and Guimberteau, M.: Projected strengthening of amazonian dry season by constrained climate model simulations, Nature Climate Change, 5, 656-660, doi:10.1038/nclimate2658, 2015.

Brando, P. M., Goetz, S. J., Baccini, A., Nepstad, D. C., Beck, P. S. A., and Christman, M. C.: Seasonal and interannual variability of climate and vegetation indices across the amazon, P. Natl. Acad. Sci. USA, 107, 14685-14690, 2010.

Chavana-Bryant, C., Malhi, Y., Wu, J., Asner, G. P., Anastasiou, A., Enquist, B. J., Cosio Caravasi, E. G., Doughty, C. E., Saleska, S. R., Martin, R. E., and Gerard, F. F.: Leaf aging of amazonian canopy trees as revealed by spectral and physiochemical measurements, New Phytol., doi:10.1111/nph.13853, 2016.

Chave, J., Navarrete, D., Almeida, S., Álvarez, E., Aragão, L. E. O. C., Bonal, D., Châtelet, P., Silva-Espejo, J. E., Goret, J.-Y., von Hildebrand, P., Jiménez, E., Patiño, S., Peñuela, M. C., Phillips, O. L., Stevenson, P., and Malhi, Y.: Regional and seasonal patterns of litterfall in tropical South America, Biogeosciences, 7, 43-55, doi:10.5194/bg-7-43-2010, 2010.

Chen, Y., Randerson, J. T., Van Der Werf, G. R., Morton, D. C., $\mathrm{Mu}, \mathrm{M}$., and Kasibhatla, P. S.: Nitrogen deposition in tropical forests from savanna and deforestation fires, Glob. Change Biol., 16, 2024-2038, doi:10.1111/j.1365-2486.2009.02156.x, 2010.

Chen, Y., Morton, D. C., Jin, Y., Collatz, G. J., Kasibhatla, P. S., van der Werf, G. R., DeFries, R. S., and Randerson, J. T.: Long-term trends and interannual variability of forest, savanna and agricultural fires in south america, Carbon Management, 4, 617-638, doi:10.4155/cmt.13.61, 2013a.

Chen, Y., Velicogna, I., Famiglietti, J. S., and Randerson, J. T.: Satellite observations of terrestrial water storage provide early warning information about drought and fire season severity in the amazon, J. Geophys. Res.-Biogeo., 118, 495-504, doi:10.1002/jgrg.20046, 2013b.

Cirino, G. G., Souza, R. A. F., Adams, D. K., and Artaxo, P.: The effect of atmospheric aerosol particles and clouds on net ecosystem 
exchange in the Amazon, Atmos. Chem. Phys., 14, 6523-6543, doi:10.5194/acp-14-6523-2014, 2014.

Clark, D. B., Mercado, L. M., Sitch, S., Jones, C. D., Gedney, N., Best, M. J., Pryor, M., Rooney, G. G., Essery, R. L. H., Blyth, E., Boucher, O., Harding, R. J., Huntingford, C., and Cox, P. M.: The Joint UK Land Environment Simulator (JULES), model description - Part 2: Carbon fluxes and vegetation dynamics, Geosci. Model Dev., 4, 701-722, doi:10.5194/gmd-4-701-2011, 2011.

Cleveland, C. C., Taylor, P., Chadwick, K. D., Dahlin, K., Doughty, C. E., Malhi, Y., Smith, W. K., Sullivan, B. W., Wieder, W. R., and Townsend, A. R.: A comparison of plot-based satellite and earth system model estimates of tropical forest net primary production, Global Biogeochem. Cy., 29, 626-644, doi:10.1002/2014GB005022, 2015.

Cox, P. M., Pearson, D., Booth, B. B., Friedlingstein, P., Huntingford, C., Jones, C. D., and Luke, C. M.: Sensitivity of tropical carbon to climate change constrained by carbon dioxide variability, Nature, 494, 341-344, 2013.

da Costa, A. C. L., Galbraith, D., Almeida, S., Portela, B. T. T., da Costa, M., de Athaydes Silva Junior, J., Braga, A. P., de Gonçalves, P. H. L., de Oliveira, A. A. R., Fisher, R., Phillips, O. L., Metcalfe, D. B., Levy, P., and Meir, P.: Effect of $7 \mathrm{yr}$ of experimental drought on vegetation dynamics and biomass storage of an eastern amazonian rainforest, New Phytol., 187, 579-591, doi:10.1111/j.1469-8137.2010.03309.x, 2010.

Doughty, C. E. and Goulden, M. L.: Are tropical forests near a high temperature threshold?, J. Geophys. Res.-Biogeo., 113, G00B07, doi:10.1029/2007JG000632, 2008.

Doughty, C. E., Metcalfe, D. B., Girardin, C. A. J., Amezquita, F. F., Durand, L., Huaraca Huasco, W., Silva-Espejo, J. E., AraujoMurakami, A., da Costa, M. C., da Costa, A. C. L., Rocha, W., Meir, P., Galbraith, D., and Malhi, Y.: Source and sink carbon dynamics and carbon allocation in the amazon basin, Global Biogeochem. Cy., 29, 645-655, doi:10.1002/2014GB005028, 2015.

Espírito-Santo, F. D. B., Gloor, M., Keller, M., Malhi, Y., Saatchi, S., Nelson, B., Junior, R. C. O., Pereira, C., Lloyd, J., Frolking, S., Palace, M., Shimabukuro, Y. E., Duarte, V., Mendoza, A. M., López-González, G., Baker, T. R., Feldpausch, T. R., Brienen, R. J. W., Asner, G. P., Boyd, D. S., and Phillips, O. L.: Size and frequency of natural forest disturbances and the amazon forest carbon balance, Nat. Commun., 5, 3434, doi:10.1038/ncomms4434, 2014.

Frolking, S., Milliman, T., Palace, M., Wisser, D., Lammers, R., and Fahnestock, M.: Tropical forest backscatter anomaly evident in seawinds scatterometer morning overpass data during 2005 drought in amazonia, Remote Sens. Environ., 115, 897907, 2011.

Gastellu-Etchegorry, J. P. and Trichon, V.: A modeling approach of par environment in a tropical rain forest in sumatra: Application to remote sensing, Ecol. Model., 108, 237-264, doi:10.1016/S0304-3800(98)00032-5, 1998.

Gastellu-Etchegorry, J. P., Grau, E., and Lauret, N.: Dart: A 3d model for remote sensing images and radiative budget of earth surfaces, in: Modeling and simulation in engineering, edited by: Alexandru, C., InTech, ISBN:978-953-951-0012-0016, 2012.

Gastellu-Etchegorry, J.-P., Yin, T., Lauret, N., Cajgfinger, T., Gregoire, T., Grau, E., Feret, J.-B., Lopes, M., Guilleux, J., Dedieu, G., Malenovský, Z., Cook, B., Morton, D., Rubio, J., Durrieu, S., Cazanave, G., Martin, E., and Ristorcelli, T.: Discrete anisotropic radiative transfer (dart 5) for modeling airborne and satellite spectroradiometer and lidar acquisitions of natural and urban landscapes, Remote Sens., 7, 1667-1701, 2015.

Gatti, L. V., Miller, J. B., D’Amelio, M. T. S., Martinewski, A., Basso, L. S., Gloor, M. E., Wofsy, S., and Tans, P.: Vertical profiles of $\mathrm{CO}_{2}$ above eastern amazonia suggest a net carbon flux to the atmosphere and balanced biosphere between 2000 and 2009, Tellus B, 62, 581-594, 2010.

Gatti, L. V., Gloor, M., Miller, J. B., Doughty, C. E., Malhi, Y., Domingues, L. G., Basso, L. S., Martinewski, A., Correia, C. S. C., Borges, V. F., Freitas, S., Braz, R., Anderson, L. O., Rocha, H., Grace, J., Phillips, O. L., and Lloyd, J.: Drought sensitivity of amazonian carbon balance revealed by atmospheric measurements, Nature, 506, 76-80, doi:10.1038/nature12957, 2014.

Gibelin, A.-L., Calvet, J.-C., and Viovy, N.: Modelling energy and $\mathrm{CO}_{2}$ fluxes with an interactive vegetation land surface modelevaluation at high and middle latitudes, Agr. Forest Meteorol., 148, 1611-1628, doi:10.1016/j.agrformet.2008.05.013, 2008.

Grau, E. and Gastellu-Etchegorry, J.-P.: Radiative transfer modeling in the earth-atmosphere system with dart model, Remote Sens. Environ., 139, 149-170, doi:10.1016/j.rse.2013.07.019, 2013.

Guan, K., Pan, M., Li, H., Wolf, A., Wu, J., Medvigy, D., Caylor, K. K., Sheffield, J., Wood, E. F., Malhi, Y., Liang, M., Kimball, J. S., Saleska, S. R., Berry, J., Joiner, J., and Lyapustin, A. I.: Photosynthetic seasonality of global tropical forests constrained by hydroclimate, Nat. Geosci., 8, 284-289, doi:10.1038/ngeo2382, 2015.

Guillevic, P. and Gastellu-Etchegorry, J. P.: Modeling brf and radiation regime of boreal and tropical forest: Ii. Par regime, Remote Sens. Environ., 68, 317-340, doi:10.1016/S00344257(98)00120-5, 1999.

Higuchi, N., dos Santos, J., Ribeiro, R., Minette, L., and Biot, Y.: Biomass da parte aérea da vegetação da floresta tropical úmida de terra-firme da amazônia brasileira, Acta Amazon., 28, 153-166, 1998.

Holben, B. N., Eck, T. F., Slutsker, I., Tanré, D., Buis, J. P., Setzer, A., Vermote, E., Reagan, J. A., Kaufman, Y. J., Nakajima, T., Lavenu, F., Jankowiak, I., and Smirnov, A.: Aeronet - a federated instrument network and data archive for aerosol characterization, Remote Sens. Environ., 66, 1-16, doi:10.1016/S00344257(98)00031-5, 1998.

Huete, A. R., Didan, K., Shimabukuro, Y. E., Ratana, P., Saleska, S. R., Hutyra, L. R., Yang, W., Nemani, R. R., and Myneni, R. B.: Amazon rainforests green-up with sunlight in dry season, Geophys. Res. Lett., 33, L06405, doi:10.1029/2005GL025583, 2006.

Hunter, M. O., Keller, M., Morton, D., Cook, B., Lefsky, M., Ducey, M., Saleska, S., de Oliveira Jr., R. C., and Schietti, J.: Structural dynamics of tropical moist forest gaps, PLoS ONE, 10, e0132144, doi:10.1371/journal.pone.0132144, 2015.

Hutyra, L. R., Munger, J. W., Saleska, S. R., Gottlieb, E., Daube, B. C., Dunn, A. L., Amaral, D. F., de Camargo, P. B., and Wofsy, S. C.: Seasonal controls on the exchange of carbon and water in an amazonian rain forest, J. Geophys. Res.-Biogeo., 112, G03008, doi:10.1029/2006JG000365, 2007.

Hutyra, L. R., Wofsy, S. C., and Saleska, S. R.: Lba-eco cd-10 CO 2 and $\mathrm{H}_{2} \mathrm{O}$ eddy fluxes at $\mathrm{km} 67$ tower site, tapajos national forest, in, ORNL Distributed Active Archive Center, 2008.

Joiner, J., Yoshida, Y., Vasilkov, A. P., Yoshida, Y., Corp, L. A., and Middleton, E. M.: First observations of global and seasonal 
terrestrial chlorophyll fluorescence from space, Biogeosciences, 8, 637-651, doi:10.5194/bg-8-637-2011, 2011.

Kanniah, K. D., Beringer, J., North, P., and Hutley, L.: Control of atmospheric particles on diffuse radiation and terrestrial plant productivity: A review, Prog. Phys. Geog., 36, 209-237, 2012.

Keppel-Aleks, G., Wolf, A. S., Mu, M., Doney, S. C., Morton, D. C., Kasibhatla, P. S., Miller, J. B., Dlugokencky, E. J., and Randerson, J. T.: Separating the influence of temperature, drought, and fire on interannual variability in atmospheric $\mathrm{CO}_{2}$, Global Biogeochem. Cy., 28, 1295-1310, doi:10.1002/2014GB004890, 2014.

Kitajima, K., Mulkey, S. S., and Wright, S. J.: Seasonal leaf phenotypes in the canopy of a tropical dry forest: Photosynthetic characteristics and associated traits, Oecologia, 109, 490-498, doi:10.1007/s004420050109, 1997.

Krinner, G., Viovy, N., de Noblet-Ducoudré, N., Ogée, J., Polcher, J., Friedlingstein, P., Ciais, P., Sitch, S., and Prentice, I. C.: A dynamic global vegetation model for studies of the coupled atmosphere-biosphere system, Global Biogeochem. Cy., 19, GB1015, doi:10.1029/2003GB002199, 2005.

Le Quéré, C., Andres, R. J., Boden, T., Conway, T., Houghton, R. A., House, J. I., Marland, G., Peters, G. P., van der Werf, G. R., Ahlström, A., Andrew, R. M., Bopp, L., Canadell, J. G., Ciais, P., Doney, S. C., Enright, C., Friedlingstein, P., Huntingford, C., Jain, A. K., Jourdain, C., Kato, E., Keeling, R. F., Klein Goldewijk, K., Levis, S., Levy, P., Lomas, M., Poulter, B., Raupach, M. R., Schwinger, J., Sitch, S., Stocker, B. D., Viovy, N., Zaehle, S., and Zeng, N.: The global carbon budget 1959-2011, Earth Syst. Sci. Data, 5, 165-185, doi:10.5194/essd-5-165-2013, 2013.

Lee, J.-E., Frankenberg, C., van der Tol, C., Berry, J. A., Guanter, L., Boyce, C. K., Fisher, J. B., Morrow, E., Worden, J. R., Asefi, S., Badgley, G., and Saatchi, S.: Forest productivity and water stress in amazonia: Observations from gosat chlorophyll fluorescence, P. Roy. Soc. Lond. B Bio., 280, 20130171, doi:10.1098/rstb.2012.0163, 2013.

Leitold, V., Keller, M., Morton, D. C., Cook, B. D., and Shimabukuro, Y. E.: Airborne lidar-based estimates of tropical forest structure in complex terrain: Opportunities and trade-offs for redd+, Carbon Balance Manag., 10, 3, doi:10.1186/s13021015-0013-x, 2015.

Lewis, S. L., Brando, P. M., Phillips, O. L., van der Heijden, G. M. F., and Nepstad, D.: The 2010 amazon drought, Science, 331, 554-554, 2011.

Longo, M.: Amazon forest response to changes in rainfall regime: Results from an individual-based dynamic vegetation model, PhD, Harvard University, Cambridge, MA, 2014.

Malhi, Y., Wood, D., Baker, T. R., Wright, J., Phillips, O. L., Cochrane, T., Meir, P., Chave, J., Killeen, T. J., Laurance, S. G., Laurance, W. F., Vargas, P. N., Pitman, N. C. A., Quesada, C. A., Salomão, R., Silva, J. N., Lezama, A. T., Terborgh, J., Martínez, R. V., and Vinceti, B.: The regional variation of aboveground live biomass in old-growth amazonian forests, Glob. Change Biol., 12, 1-32, 2006.

Malhi, Y., Doughty, C. E., Goldsmith, G. R., Metcalfe, D. B., Girardin, C. A. J., Marthews, T. R., del Aguila-Pasquel, J., Aragão, L. E. O. C., Araujo-Murakami, A., Brando, P., da Costa, A. C. L., Silva-Espejo, J. E., Farfán Amézquita, F., Galbraith, D. R., Quesada, C. A., Rocha, W., Salinas-Revilla, N., Silvério, D., Meir, P., and Phillips, O. L.: The linkages between photosynthesis, productivity, growth and biomass in lowland amazonian forests, Glob. Change Biol., 21, 2283-2295, doi:10.1111/gcb.12859, 2015.

Medvigy, D., Jeong, S.-J., Clark, K. L., Skowronski, N. S., and Schäfer, K. V. R.: Effects of seasonal variation of photosynthetic capacity on the carbon fluxes of a temperate deciduous forest, J. Geophys. Res.-Biogeo., 118, 1703-1714, doi:10.1002/2013JG002421, 2013.

Mercado, L. M., Bellouin, N., Sitch, S., Boucher, O., Huntingford, C., Wild, M., and Cox, P. M.: Impact of changes in diffuse radiation on the global land carbon sink, Nature, 458, 1014-1017, 2009.

Moorcroft, P. R., Hurtt, G. C., and Pacala, S. W.: A method for scaling vegetation dynamics: The ecosystem demography model, Ecol. Monogr., 71, 557-586, 2001.

Morton, D. C., Le Page, Y., DeFries, R. S., Collatz, G. J., and Hurtt, G. C.: Understorey fire frequency and the fate of burned forests in southern amazonia, Philos. T. R. Soc. B, 368, 20120163, doi:10.1098/rstb.2012.0163, 2013.

Morton, D. C., Nagol, J., Carabajal, C. C., Rosette, J., Palace, M., Cook, B. D., Vermote, E. F., Harding, D. J., and North, P. R. J.: Amazon forests maintain consistent canopy structure and greenness during the dry season, Nature, 506, 221-224, doi:10.1038/nature13006, 2014.

Nagol, J. R., Sexton, J. O., Kim, D.-H., Anand, A., Morton, D., Vermote, E., and Townshend, J. R.: Bidirectional effects in landsat reflectance estimates: Is there a problem to solve?, ISPRS J. Photogramm., 103, 129-135, doi:10.1016/j.isprsjprs.2014.09.006, 2015.

Nemani, R. R., Keeling, C. D., Hashimoto, H., Jolly, W. M., Piper, S. C., Tucker, C. J., Myneni, R. B., and Running, S. W.: Climatedriven increases in global terrestrial net primary production from 1982 to 1999, Science, 300, 1560-1563, 2003.

Nepstad, D. C., Tohver, I. M., Ray, D., Moutinho, P., and Cardinot, G.: Mortality of large trees and lianas following experimental drought in an amazon forest, Ecology, 88, 2259-2269, 2007.

Oliveira, P. H. F., Artaxo, P., Pires, C., De Lucca, S., ProcÓPio, A., Holben, B., Schafer, J., Cardoso, L. F., Wofsy, S. C., and Rocha, H. R.: The effects of biomass burning aerosols and clouds on the $\mathrm{CO}_{2}$ flux in amazonia, Tellus B, 59, 338-349, doi:10.1111/j.1600-0889.2007.00270.x, 2007.

Parazoo, N. C., Bowman, K., Frankenberg, C., Lee, J.-E., Fisher, J. B., Worden, J., Jones, D. B. A., Berry, J., Collatz, G. J., Baker, I. T., Jung, M., Liu, J., Osterman, G., O'Dell, C., Sparks, A., Butz, A., Guerlet, S., Yoshida, Y., Chen, H., and Gerbig, C.: Interpreting seasonal changes in the carbon balance of southern amazonia using measurements of xco2 and chlorophyll fluorescence from gosat, Geophys. Res. Lett., 40, 2829-2833, doi:10.1002/grl.50452, 2013.

Phillips, O. L., Aragão, L. E. O. C., Lewis, S. L., Fisher, J. B., Lloyd, J., López-González, G., Malhi, Y., Monteagudo, A., Peacock, J., Quesada, C. A., van der Heijden, G., Almeida, S., Amaral, I. d., Arroyo, L., Aymard, G., Baker, T. R., Bánki, O., Blanc, L., Bonal, D., Brando, P., Chave, J., de Oliveira, Å. C. A., Cardozo, N. D. v., Czimczik, C. I., Feldpausch, T. R., Freitas, M. A., Gloor, E., Higuchi, N., Jiménez, E., Lloyd, G., Meir, P., Mendoza, C., Morel, A., Neill, D. A., Nepstad, D., Patiño, S., Peñuela, M. C., Prieto, A., Ramv?rez, F., Schwarz, M., Silva, J., Silveira, M., Thomas, A. S., Steege, H. t., Stropp, J., Vásquez, R., Zelazowski, 
P., Dávila, E. A., Andelman, S., Andrade, A., Chao, K.-J., Erwin, T., Di Fiore, A., C, E. d. H., Keeling, H., Killeen, T. J., Laurance, W. F., Cruz, A. P. A., Pitman, N. C. A., Vargas, P. N. e., RamírezAngulo, H., Rudas, A. N., Salamão, R., Silva, N., Terborgh, J., and Torres-Lezama, A.: Drought sensitivity of the amazon rainforest, Science, 323, 1344-1347, 2009.

Poulter, B., Frank, D., Ciais, P., Myneni, R. B., Andela, N., Bi, J., Broquet, G., Canadell, J. G., Chevallier, F., Liu, Y. Y., Running, S. W., Sitch, S., and van der Werf, G. R.: Contribution of semiarid ecosystems to interannual variability of the global carbon cycle, Nature, 509, 600-603, doi:10.1038/nature13376, 2014.

Randerson, J. T.: Climate science: Global warming and tropical carbon, Nature, 494, 319-320, 2013.

Rap, A., Spracklen, D. V., Mercado, L., Reddington, C. L., Haywood, J. M., Ellis, R. J., Phillips, O. L., Artaxo, P., Bonal, D., Restrepo Coupe, N., and Butt, N.: Fires increase amazon forest productivity through increases in diffuse radiation, Geophys. Res. Lett., 42, 4654-4662, doi:10.1002/2015GL063719, 2015.

Restrepo-Coupe, N., da Rocha, H. R., Hutyra, L. R., da Araujo, A. C., Borma, L. S., Christoffersen, B., Cabral, O. M. R., de Camargo, P. B., Cardoso, F. L., da Costa, A. C. L., Fitzjarrald, D. R., Goulden, M. L., Kruijt, B., Maia, J. M. F., Malhi, Y. S., Manzi, A. O., Miller, S. D., Nobre, A. D., von Randow, C., Sá, L. D. A., Sakai, R. K., Tota, J., Wofsy, S. C., Zanchi, F. B., and Saleska, S. R.: What drives the seasonality of photosynthesis across the amazon basin? A cross-site analysis of eddy flux tower measurements from the brasil flux network, Agr. Forest Meteorol., 182183, 128-144, doi:10.1016/j.agrformet.2013.04.031, 2013.

Romanczyk, P., van Aardt, J., Cawse-Nicholson, K., Kelbe, D., McGlinchy, J., and Krause, K.: Assessing the impact of broadleaf tree structure on airborne full-waveform small-footprint lidar signals through simulation, Can. J. Remote Sens., 39, S60-S72, doi:10.5589/m13-015, 2013.

Saatchi, S., Asefi-Najafabady, S., Malhi, Y., Aragão, L. E. O. C., Anderson, L. O., Myneni, R. B., and Nemani, R.: Persistent effects of a severe drought on amazonian forest canopy, P. Natl. Acad. Sci. USA, 110, 565-570, 2013.

Saatchi, S. S., Harris, N. L., Brown, S., Lefsky, M., Mitchard, E. T. A., Salas, W., Zutta, B. R., Buermann, W., Lewis, S. L., Hagen, S., Petrova, S., White, L., Silman, M., and Morel, A.: Benchmark map of forest carbon stocks in tropical regions across three continents, P. Natl. Acad. Sci. USA, 108, 98999904, doi:10.1073/pnas.1019576108, 2011.

Saleska, S. R., Miller, S. D., Matross, D. M., Goulden, M. L., Wofsy, S. C., da Rocha, H. R., de Camargo, P. B., Crill, P., Daube, B. C., de Freitas, H. C., Hutyra, L. R., Keller, M., Kirchhoff, V., Menton, M., Munger, J. W., Pyle, E. H., Rice, A. H., and Silva, H.: Carbon in amazon forests: Unexpected seasonal fluxes and disturbance-induced losses, Science, 302, 1554-1557, 2003.

Samanta, A., Knyazikhin, Y., Xu, L., Dickinson, R. E., Fu, R., Costa, M. H., Saatchi, S. S., Nemani, R. R., and Myneni, R. B.: Seasonal changes in leaf area of amazon forests from leaf flushing and abscission, J. Geophys. Res., 117, G01015, doi:10.1029/2011jg001818, 2012.

Scheiter, S., Langan, L., and Higgins, S. I.: Next-generation dynamic global vegetation models: Learning from community ecology, New Phytol., 198, 957-969, doi:10.1111/nph.12210, 2013.

Schimel, D., Pavlick, R., Fisher, J. B., Asner, G. P., Saatchi, S., Townsend, P., Miller, C., Frankenberg, C., Hibbard, K., and Cox, P.: Observing terrestrial ecosystems and the carbon cycle from space, Glob. Change Biol., 21, 1762-1776, doi:10.1111/gcb.12822, 2015.

Sellers, P. J., Berry, J. A., Collatz, G. J., Field, C. B., and Hall, F. G.: Canopy reflectance, photosynthesis, and transpiration. Iii. A reanalysis using improved leaf models and a new canopy integration scheme, Remote Sens. Environ., 42, 187-216, doi:10.1016/0034-4257(92)90102-P, 1992.

Senna, M. C. A., Costa, M. H., and Shimabukuro, Y. E.: Fraction of photosynthetically active radiation absorbed by amazon tropical forest: A comparison of field measurements, modeling, and remote sensing, J. Geophys. Res.-Biogeo., 110, G01008, doi:10.1029/2004JG000005, 2005.

Sitch, S., Smith, B., Prentice, I. C., Arneth, A., Bondeau, A., Cramer, W., Kaplan, J. O., Levis, S., Lucht, W., Sykes, M. T., Thonicke, K., and Venevsky, S.: Evaluation of ecosystem dynamics, plant geography and terrestrial carbon cycling in the lpj dynamic global vegetation model, Glob. Change Biol., 9, 161-185, doi:10.1046/j.1365-2486.2003.00569.x, 2003.

Stark, S. C., Leitold, V., Wu, J. L., Hunter, M. O., de Castilho, C. V., Costa, F. R. C., McMahon, S. M., Parker, G. G., Shimabukuro, M. T., Lefsky, M. A., Keller, M., Alves, L. F., Schietti, J., Shimabukuro, Y. E., Brandão, D. O., Woodcock, T. K., Higuchi, N., de Camargo, P. B., de Oliveira, R. C., and Saleska, S. R.: Amazon forest carbon dynamics predicted by profiles of canopy leaf area and light environment, Ecol. Lett., 15, 1406-1414, doi:10.1111/j.1461-0248.2012.01864.x, 2012.

ter Steege, H., Pitman, N. C. A., Sabatier, D., Baraloto, C., Salomão, R. P., Guevara, J. E., Phillips, O. L., Castilho, C. V., Magnusson, W. E., Molino, J.-F., Monteagudo, A., Núñez Vargas, P., Montero, J. C., Feldpausch, T. R., Coronado, E. N. H., Killeen, T. J., Mostacedo, B., Vasquez, R., Assis, R. L., Terborgh, J., Wittmann, F., Andrade, A., Laurance, W. F., Laurance, S. G. W., Marimon, B. S., Marimon, B.-H., Guimarães Vieira, I. C., Amaral, I. L., Brienen, R., Castellanos, H., Cárdenas López, D., Duivenvoorden, J. F., Mogollón, H. F., Matos, F. D. d. A., Dávila, N., GarcíaVillacorta, R., Stevenson Diaz, P. R., Costa, F., Emilio, T., Levis, C., Schietti, J., Souza, P., Alonso, A., Dallmeier, F., Montoya, A. J. D., Fernandez Piedade, M. T., Araujo-Murakami, A., Arroyo, L., Gribel, R., Fine, P. V. A., Peres, C. A., Toledo, M., Aymard C, G. A., Baker, T. R., Cerón, C., Engel, J., Henkel, T. W., Maas, P., Petronelli, P., Stropp, J., Zartman, C. E., Daly, D., Neill, D., Silveira, M., Paredes, M. R., Chave, J., Lima Filho, D. d. A., Jørgensen, P. M., Fuentes, A., Schöngart, J., Cornejo Valverde, F., Di Fiore, A., Jimenez, E. M., Peñuela Mora, M. C., Phillips, J. F., Rivas, G., van Andel, T. R., von Hildebrand, P., Hoffman, B., Zent, E. L., Malhi, Y., Prieto, A., Rudas, A., Ruschell, A. R., Silva, N., Vos, V., Zent, S., Oliveira, A. A., Schutz, A. C., Gonzales, T., Trindade Nascimento, M., Ramirez-Angulo, H., Sierra, R., Tirado, M., Umaña Medina, M. N., van der Heijden, G., Vela, C. I. A., Vilanova Torre, E., Vriesendorp, C., Wang, O., Young, K. R., Baider, C., Balslev, H., Ferreira, C., Mesones, I., TorresLezama, A., Urrego Giraldo, L. E., Zagt, R., Alexiades, M. N., Hernandez, L., Huamantupa-Chuquimaco, I., Milliken, W., Palacios Cuenca, W., Pauletto, D., Valderrama Sandoval, E., Valenzuela Gamarra, L., Dexter, K. G., Feeley, K., Lopez-Gonzalez, G., and Silman, M. R.: Hyperdominance in the amazonian tree flora, Science, 342, doi:10.1126/science.1243092, 2013. 
van der Tol, C., Verhoef, W., Timmermans, J., Verhoef, A., and Su, Z.: An integrated model of soil-canopy spectral radiances, photosynthesis, fluorescence, temperature and energy balance, Biogeosciences, 6, 3109-3129, doi:10.5194/bg-6-3109-2009, 2009.

Widlowski, J. L., Pinty, B., Clerici, M., Dai, Y., De Kauwe, M., de Ridder, K., Kallel, A., Kobayashi, H., Lavergne, T., Ni-Meister, W., Olchev, A., Quaife, T., Wang, S., Yang, W., Yang, Y., and Yuan, H.: Rami4pilps: An intercomparison of formulations for the partitioning of solar radiation in land surface models, J. Geophys. Res.-Biogeo., 116, G02019, doi:10.1029/2010JG001511, 2011.

Wu, J., Albert, L. P., Lopes, A. P., Restrepo-Coupe, N., Hayek, M., Wiedemann, K. T., Guan, K., Stark, S. C., Christoffersen, B., Prohaska, N., Tavares, J. V., Marostica, S., Kobayashi, H., Ferreira, M. L., Campos, K. S., da Silva, R., Brando, P. M., Dye, D. G., Huxman, T. E., Huete, A. R., Nelson, B. W., and Saleska, S. R.: Leaf development and demography explain photosynthetic seasonality in amazon evergreen forests, Science, 351, 972-976, 2016.
Zeng, N., Zhao, F., Collatz, G. J., Kalnay, E., Salawitch, R. J., West, T. O., and Guanter, L.: Agricultural green revolution as a driver of increasing atmospheric $\mathrm{CO}_{2}$ seasonal amplitude, Nature, 515, 394-397, doi:10.1038/nature13893, 2014.

Zhang, Y., Guanter, L., Berry, J. A., Joiner, J., van der Tol, C., Huete, A., Gitelson, A., Voigt, M., and Köhler, P.: Estimation of vegetation photosynthetic capacity from space-based measurements of chlorophyll fluorescence for terrestrial biosphere models, Glob. Change Biol., 20, 3727-3742, doi:10.1111/gcb.12664, 2014. 